termined partly by the quality of reproduction, but probably more by the freedom it enjoys from interference from extraneous sounds. It is primarily programme interest which pleases, but interference is very objectionable however good the programme. The author acknowledges his thanks to the B.B.C. for providing the funds for the construction of test apparatus. He also thanks the Countess von Zeppelin for her mathematical investigation, given in an appendix, resulting in a most useful expression for the distortion component.

\section{Reclamation of Tidal Lands}

Is a lecture delivered before the Royal Society of Arts on February 23, Mr. Oscar Borer described the process of land reclamation work as applied to the coastal frontages on both sides of the North Sea, tracing the origin of such operations to the time of the Romans under whose direction a bank was constructed across the Wash at some date prior to A.D. 359, and when other embankments were made between Lincoln and Norwich, aggregating not less than 50 miles in length and having a height of 10 feet. After the cessation of the Roman occupation, very little additional protection seems to have been undertaken along the British coastline until the seventeenth century, when during the reign of James I and afterwards, large tracts of marshlands, amounting to 35,000 acres, were excluded from tidal influence. During the eighteenth and nineteenth centuries, other areas approximating to 10,000 acres were reclaimed. Of the total quantity enclosed since Roman times, 8,000 acres was marshland in Norfolk along a frontage of ten miles, and 37,000 acres in the South Holland district of Lincolnshire with a frontage of nineteen miles, the remainder being in the North Holland district. In the Netherlands, from Roman times until the beginning of the fifteenth century, extensive areas were lost to cultivation through floods, the surface level of the land having sunk so that it was easily invaded. Early dikes made to offer defence against the sea broke down, and in this way the Dollart was formed in the twelfth or thirteenth century. The Zuider Zee, which had once been largely dry land, was inundated about the same time. The largest 'polder' recently reclaimed in this area is the Wieringermeer, in the north-west corner. It has an area of 48,000 acres and was dried in 1930. A second enclosure in the north-east corner was started in 1936, and it is expected that in due course another 110,000 acres will be available for agriculture. On the German North Sea coast, 8,000 acres has been embanked since 1900 in the province of Schleswig-Holstein.

\section{The Disappearing Fauna of Africa}

THE problem of the disappearing fauna of Africa formed the subject of a lecture before the University of London Animal Welfare Society on March 7. It has been common knowledge for years that the status of many of the big African animals was precarious. The last quagga died in 1882, and the three big pachyderms have been killed off at an alarming rate. Not only are the indigenous beasts being wiped out under the 'protecting' eye of a white civilization, but also the majority of many species are dying unnecessarily cruel deaths at the hands of the African native, working with old-fashioned guns and pitfalls and traps. Possibly only a few thousand gorillas remain alive to-day, in the Cameroons, where they are exploited by man, and in the Parc National Albert, where they are protected by the Belgian Government. The elephant has disappeared from most of its old haunts. In the three British dependencies a minimum of 6,000 a year are killed, chiefly in the 'control campaign'. Tanganyika and the lake swamps are the last haunts of the hippopotamus, and unless help is forthcoming this will eventually disappear. On November 8, 1933, the London Convention for the Protection of the African Fauna and Flora was signed. The first of a series of subsequent international conferences should have taken place before November 1937. No conference has been held, the reason given being that the British Government intends to summon a conference on tropical Asia and the western Pacific, certain of the experts interested in those regions being also interested in Africa. At the meeting, the Society passed a resolution calling upon the Government to take urgent steps for summoning the London Convention for the Protection of the African Fauna promised for November 1937.

\section{Locust Outbreaks in Africa and Western Asia}

THE recent report of the Committee on Locust Control is the sixth of its kind which deals with locust outbreaks in the regions mentioned. In the present instance it covers the year 1936 and the early part of 1937, and has been prepared by $\mathrm{Dr}$. B. P. Uvarov and Miss W. Milnthorpe. The report is a survey of the conditions in the territory named and is based upon the accumulated data which has come to hand as the result of international organization. It appears that the general situation, in so far as the African migratory locust and the red locust are concerned, is steadily improving. Particular stress, however, is laid on the beginning of a new outbreak of the desert locust which has been definitely proved to be forming in the Sudanese-Arabian area. It has been due to the regular system which is operating for the recording and collection of all data relating to locusts, and its centralization in a single institution (the Imperial Institute of Entomology), that the first signs of this outbreak have been recognized and warnings issued to all countries likely to be affected by the locust in question. The concerted measures which are being undertaken in order to endeavour to fathom the causes of locust outbreaks merit every support. The elaborate organization which has been built up and got into working order at the prime instigation of Dr. Uvarov provides the only sound method of attack-mere remedial measures are temporary palliatives and leave the locust menace unimpaired. At the present stage of the work, no effort should be relaxed, and it is up to the countries directly interested to see that the necessary funds are maintained. The report is available, price $3 s$. net, and is published by H.M. Stationery Office. 